Центр воєнно-стратегічних досліджень Національного університету оборони України імені Івана Черняхівського, Київ

\title{
Геополітичні характеристики як форма реалізації геополітики
}

Резюме. У статті розглянуто зміст гіпотези, яка підтверджує необхідність дослідження геополітичних характеристик як важливого показника впливу на геополітику та агресивність держав.

Ключові слова: воєнно-політична обстановка; геополітика; геополітична характеристика; агресія; агресивність; прогноз воєнно-політичної обстановки.

Постановка проблеми. Сучасне геополітичне становище змушує Україну виробляти у зовнішній регіональній політиці правила відношень, адекватні ситуації в світі та водночас відповідні іiі власним національним інтересам, геополітичному i геостратегічному положенню в регіональній і глобальній міжнародній системі. Ці обставини вимагають від лідерів держави активності у зовнішній політиці. Незалежність України зумовлює гостру потребу геополітичних досліджень із залученням сучасних теоретикометодологічних засад геополітики. 3 огляду на особливості сучасної міжнародної системи, геополітичне положення України, вони сприяли б реалізації пріоритетних напрямів зовнішньої політики нашої держави.

Аналіз останніх досліджень i публікацій. Геополітика, як явище, дедалі частіше стає предметом аналізу серед політиків, громадських діячів, аналітиків та вчених. Нині маємо нагоду спостерігати зміну парадигм міжнародного буття та становлення нової геополітичної картини світу. Найбільш проблематика геополітики розкривається у працях західних вчених, оскільки саме Європа $\epsilon$ місцем ऑiі зародження й динамічного розвитку. Серед західних представників, що інтерпретують геополітику або використовують іiі як методологію варто виділити імена: Л. Арона, 3. Бжезинського [1], T. Грема, С. Делбі [2], Дж. Егню [3], Е. Качинса, М. Макфола, Дж. Міршаймера [4], О. Мотиля та ін. На жаль, в Україні геополітика майже не представлена окремим науковим напрямом чи конкретними науковими школами. Утім, такі вчені як М. Дністрянський, О. Білорус, М. Дорошко [5], Г. Перепелиця [6], Л. Чекаленко [7], В. Бочарніков, С. Свєшніков все ж активно використовують методологічний аспект геополітики в своїх наукових дослідженнях.

Метою статті $\epsilon$ з'ясування складових та визначення терміну “геополітика", а також виявлення факторів, які впливають на оцінку агресивності.

Виклад основного матеріалу. Безпекове середовище довкола України складне та динамічне. Через збройний конфлікт на Сході України, воєнно-політичну нестабільність на Близькому Сході, міжнародний тероризм, загрози у кібернетичній сфері, боротьбу за вплив на світові фінансові та енергетичні потоки посилюється глобальна воєннополітична нестабільність.

Аналіз сучасних воєнно-політичних процесів, які відбуваються у світі, дає усі підстави стверджувати про зміни міжнародних відносин, які викликані прискоренням процесів глобалізації і збільшенням можливості негативного впливу іноземних держав на реалізацію національних інтересів України, пов'язаних із забезпеченням іiі суверенітету, територіальної цілісності і недопущенням втручань у внутрішні справи. Кардинально підвищилися спроможності i поширилася практика використання воєнних інструментів у досягненні воєнно-політичних цілей. Це обумовлює принципове підвищення ролі воєнної політики для реалізації національних інтересів України.

Сучасні процеси в економіці, політиці, а особливо у воєнній політиці, важко уявити без чітко осмислених, обгрунтованих дій. Отже актуальність аналізу, оцінки і прогнозування воєнно-політичної обстановки безпосередньо пов'язані 3 діяльністю щодо організації стратегічного планування державної політики, національної безпеки.

Аналіз воєнно-політичної обстановки складна i важка проблема. Проаналізувати обстановку це означає всесторонньо і глибоко вивчити властивості та закономірності явищ, та 3 урахуванням цих факторів дати оцінку, яка склалася. Під час оцінювання воєннополітичної обстановки визначаються якісні показники цього стану воєнно-політичних відносин, оскільки аналіз, що формується на 
основі первинної та вивідної аналітичної інформації, є кількісним базисом для оцінки, яка визначає воєнно-політичну обстановку. Такі критерії оцінювання воєнно-політичної обстановки, як “воєнна загроза” та “воєнна небезпека" визначають рівень воєнної безпеки і включають в себе інформацію про конкретні джерела і спрямування загрози, посягання на державний суверенітет та територіальну цілісність, втручання у внутрішні справи 3 боку інших держав, а також сукупність політичних, соціально-економічних, воєнних та інших зовнішніх і внутрішніх факторів, які 3 певних обставин здатні призвести до воєнного конфлікту.

Аналіз воєнно-політичної обстановки має за мету дати не тільки іiі оцінку, але й передбачити перспективи розвитку, що пов'язано 3 необхідністю прогнозування в майбутньому. Так само, мета прогнозування воєнно-політичної обстановки $€$ виявлення тенденцій воєнно-політичних відносин та осередків напруги, які можуть надалі привести до локальних або світових війн.

Оцінювання ВПО має важливе значення i для 3'ясування характеру сучасних воєн, конфліктів і способів їхнього ведення та для обгрунтованого пошуку ефективних напрямів підвищення бойової готовності 3С i вироблення заходів щодо планування i підготовки країни до відбиття агресії [8-16].

3 цього приводу доречна думка провідних західних фахівців щодо оцінки ВПО. В. Плєтт зазначає, що “...вона необхідна головним чином для того, щоб допомогти відповідальним керівникам розробляти та здійснювати заходи із забезпечення національної безпеки у мирний час, а під час війни - забезпечити керівництво військовими діями i підготовку стратегічних планів на післявоєнний період..." [17]. Важливість оцінювання відмічали у своїх роботах Н. Макіавеллі і Р. Хілсмен $[18,19]$. Таким чином, важливим структурним елементом воєнної безпеки, який виконує роль своєрідної зв'язуючої ланки між іiі теоретичним змістом i практичними потребами, виступає ВПО.

Виходячи 3 вищезазначеного, під воєнно-політичною обстановкою слід розуміти стан відносин між державами та коаліціями держав (націями, політичними партіями), а також контрольованими ними військовими організаціями, формуваннями, угрупованнями, що відображає на даний момент розстановку, співвідношення та взаємодію військових, економічних, політичних та інших сил $\mathrm{i}$ характеризує ступінь напруги цих відносин у даному регіоні (державі) або у світі в цілому.

Невід'ємною частиною оцінювання ВПО $є$ агресивність тієї чи іншої держави до іншого суб'єкта політичних відносин. Поняття "агресія" походить від латинського “нападати" i здавна існує в європейських мовах, однак, значення йому надавалося не завжди однакове. До початку XIX століття агресивною вважалася будь-яка активна поведінка, як доброзичлива, так і ворожа. Пізніше, значення цього слова змінилося, стало більш вузьким. Під агресією стали розуміти ворожу поведінку щодо оточуючих. Агресія (від лат. aggressio - напад) поняття сучасного міжнародного права, яке охоплює будь-яке незаконне з погляду Статуту ООН застосування збройної сили однією державою проти суверенітету, територіальної цілісності та політичної незалежності іншої держави чи народу (нації). Р. Берон i Д. Річардсон, вважають, що агресія, у будь-якій формі, являє собою стан поведінки, направлений на спричинення шкоди або збитку іншій державі, що має всі підстави уникати подібного поводження із собою. Не випадково досі немає чіткого визначення поняття “агресія". У побуті термін “агресія" має поширення для позначення насильницьких загарбницьких дій. Агресивність - ситуативний стан, який характеризується афективними спалахами гніву чи злоби та імпульсивними проявами поведінки, спрямованими на об'єкт фрустрації, що став причиною конфлікту. До агресивності близько підходить стан ворожості. Згідно 3 Басс, ворожість - вузькіший за спрямованістю стан, який завжди має певний об'єкт. Часто ворожість i агресивність поєднуються, але нерідко можливо знаходитися у ворожих відносинах, проте ніякої агресивності не виявляти хоча б тому, що заздалегідь відомі ii негативні наслідки для “агресора" [8, С. 163].

Агресивність небезпідставно має враховувати геополітичні фактори, оскільки вагомо впливає на загальну політику держави щодо інших суб'єктів. Саме країни, які мають у своїй характеристиці (проти інших країн) вагоміші, кращі, більші та вигідніші геополітичні фактори (географічне положення, площу території, багаті природні ресурси, велику чисельність населення, відповідну структуру населення тощо), як правило, і мають вагоміший вплив у світовій геополітиці та більше підстав поводити себе агресивно до інших суб'єктів світового співтовариства (США, Китай, Росія, Німеччина тощо). 
Очевидно, що оцінка потенційної агресивності принципово відрізняється від визначення акту агресії. Останній визначається на основі аналізу вже здійснених дій, а головний зміст визначення складається у зборі матеріальних доказів таких дій. На відміну від цього, оцінка потенційної агресивності базується на аналізі намірів, підстав, ознак, що носять неявний, вторинний характер. Їх невизначеність i нечіткість істотно ускладнюють розв'язання задачі оцінювання потенційної агресивності. Крім того, обтяжуючим фактором $\epsilon$ складність, багатозв'язність внутрішньої структури показників оцінювання потенційної агресивності. Дійсно, з одного боку структура показників має враховувати усі найзначущі фактори, обставини, які віддзеркалюють прагнення держави до застосування воєнної сили. 3 іншого боку, ця структура не повинна розкривати дрібні невирішальні деталі, щоб не ускладнювати процедуру оцінювання i застосування моделі на практиці. Тобто, під час побудови моделі оцінки мають дотримуватися принципу раціонального рівня системної декомпозиції. Можливо, зазначені особливості є однією з причин відсутності в сучасній науковій літературі підходів до оцінювання потенційної агресивності держави. Отже визначення впливу геополітичних характеристик на оцінювання i прогноз воєнно-політичної обстановки $\epsilon$ досить важливим завданням.

Ррозуміння геополітики існувало 3 давніх часів. Стародавні мислителі нерідко розмірковували над географічним розташуванням держав, їх кліматичними умовами, структурою населення, взаємовідносинами між державами та регіонами. Однак цей об'єкт дослідження не мав власної назви. Лише у 1916 р. шведський вчений Рудольф Челлен (1864 - 1922) увів у науку поняття “геополітика" розуміючи під нею “доктрину, що розглядає державу як географічний організм чи просторовий феномен”. Фактично, геополітика Р. Челлена розвивала давній предмет - політичну географію, не претендуючи на самодостатність. Та й сам автор не претендував на роль першовідкривача, вважаючи своїм вчителем Фрідріха Ратцеля (1844 - 1904). Ще в 1897 р. побачила світ книга Ф. Ратцеля "Політична географія”, у якій держава розглядалася як живий організм, укорінений в грунті. Для фахівців російського і німецького генеральних штабів Д. Мілютіна,
А. Снєсарєва,
Х. Мольтке-старшого

А. Шліффена геополітика була “військовою статистикою", тобто синтезом фізичної i економічної географії.

Уперше термін “геополітика" був введений Рудольфом Челленом у 1899 році. За визначенням Челлена, геополітика - це вчення про державу, як географічний організм, або явище в просторі, тобто вчення про державу, як країну, територію або область.

Геополітика (від грец. geо - Земля, politike - мистецтво управління державою) наука про географічну зумовленість різних політичних процесів. Само об'єднання слів “гео” і “політика" вказує на істотний зв'язок між географічним простором i політикою держави.

У XIX - на початку XX ст. під час дослідженя головних складових держави “територія - населення - влада" більшість вчених віддавали пріоритет території. На початку XX століття сила i вплив держави значною мірою залежали від географічного положення країни, чисельності населення та їі природних багатств. У цей період геополітика розглядала земний простір, як найважливіший pecyрс. На думку Р. Челлена, геополітика має розглядати державу, як географічний організм i, водночас, як політичний простір. Отже, держава - це земля, територія, природне середовище, населення. Пізніше геополітика набула більш широкого кола значень, вона трактується і як ідеологія, і як політичний напрям держави.

Територія і місце розташування держави спочатку виступали найважливішими ресурсами економічного і соціального прогресу країни, факторами іiі могутності, які визначають місце i роль країни у світовій політиці. Географія держав має безліч аспектів, що впливають на їхній політичний статус в глобальній політиці. Серед іншого виділяємо розміри і масштаби території країни, місце розташування, топографію, клімат, умови для сільськогосподарського виробництва, наявність природних ресурсів, доступ до морів і океанів. Таким чином, геополітика була покликана виявити зв'язок політичних i територіальних аспектів діяльності держав, залежність політичних рішень від просторового розташування політичних сил у масштабах всієї земної кулі [3].

У "Радянському енциклопедичному словнику" (1989), визначено: геополітика західна політологічна концепція, згідно з якою “політика держав, особливо зовнішня, в основному визначається різноманітними географічними факторами: просторовим 
розміщенням, наявністю або відсутністю природних ресурсів, кліматом, густотою населення і темпами його приросту”.

Відповідно до Вікіпедії: геополітика мистецтво управління державою; політологічна концепція, що вбачає у політиці засадничу, визначальну роль географічних факторів: просторове розташування країни, розмір території, наявність чи відсутність, обмеженість природних ресурсів, кількість населення.

"Геополітика служить визначенню національної політики з урахуванням факторів впливу на неї природного середовища" (Енциклопедія "Britanica”, 1994).

"Це наука, яка вивчає i аналізує в єдності географічні, історичні, політичні та інші взаємопов'язані фактори, які впливають на стратегічний потенціал держави” (“TheEncyclopedia Americana", 1973).

"Геополітика - це поєднання географічних i політичних факторів, що визначають положення держави чи регіону 3 ухилом на вплив географії на політику" (3. Бжезінський, 1997).

"Наука про вивчення відносин між владною політикою в міжнародному плані й тими географічними рамками, у яких вона проводиться" (П. Галлуа, 1990).

"Геополітика - це наука про контроль над простором" (В. Мадіссон, В. Шахов, 2003).

Оригінально надав визначення поняття геополітики російський вчений С. Переслєгін “триєдність науки, технології та трансценденціï”. Із виключно формального погляду геополітика вивчає (трактує) фізикогеографічну, економіко-географічну, расовоантропологічну, культурно-конфесійну, семантичну i, нарешті, цивілізаційну обумовленість динаміки міжнародних відносин, світової торгівлі, глобальної онтології людства.

На думку I. Гердера, розвиток цивілізації здійснюється під впливом внутрішніх і зовнішніх факторів. До останніх він зараховував фізичну природу і насамперед такі їі елементи, як клімат, грунт, географічне положення.

К. Гаджієв переконаний, що “гео” в понятті “геополітика" означає не просто географічний чи просторово-територіальний аспект у політиці тієї чи іншої держави або групи держав, воно викликане позначати всесвітньо планетарні масштаби, параметри i виміри, правила і норми поведінки загалом, а також міжнародної політики окремих держав, союзів, блоків у всесвітньому контексті.

Ще в середині 70-х років американський політолог К. Грей визначив геополітику як “науку про взаємозв'язок між фізичним середовищем і світовою політикою”.

Львівський дослідник Мирослав Дністрянський запропонував “розмежувати політичну географію i геополітику, розглядаючи політичну географію як географічну науку про територіальні особливості політичних об'єктів, процесів і явищ, геополітику - як прикладну дисципліну на стику географії, політології і політики, яка вивчає різні аспекти політичної діяльності, зумовлені такими географічними особливостями, як розташування i розміри території, природно-ресурсний потенціал, стан навколишнього середовища, розміщення соціально-економічних і політичних об'єктів тощо".

Ю. Тихонравов визначає геополітику як галузь знання, що вивчає закономірності взаємодії політики із системою неполітичних факторів, які формують географічне середовище (характер розташування, рельєф, клімат, ландшафт, корисні копалини, економіка, екологія, демографія, соціальна стратифікація, військова міць).

На думку С. Цибульського, в сучасному розумінні геополітикою називають науку, що вивчає процеси, принципи i перспективи розвитку держав, регіонів, планети загалом 3 урахуванням системного впливу географічних, політичних, економічних, військових, екологічних, етнічних та інших чинників, серед яких пріоритетними $є$ державні інтереси конкретних державних утворень, що визначаються особливостями географічного простору.

Н. Нартов, виділяючи форми контролю геополітичного простору, говорить про політичний, економічний, воєнний, демографічний, комунікаційний, релігійний, інформаційно-ідеологічний, технологічний i культурно-цивілізаційний контроль. Він вказує, що ці форми, як правило, використовуються в різних поєднаннях, оскільки геополітичний підхід потребує врахування всіх чинників у міждержавних взаємовідносинах, на передусім географічних, економічних, політичних, воєнних, демографічних, культурно-релігійних, етнічних. Тобто, це ті чинники, широкомасштабним системним впливом яких, обумовлюється геополітика держав.

Н. Спайкмен виділив десять критеріїв, що визначають геополітичну могутність держави, а 
саме: поверхня території, природа кордонів, кількість населення, наявність чи відсутність корисних копалин, економічний та технологічний розвиток, фінансова міць, етнічна однорідність, рівень соціальної інтеграції, політична стабільність, національний дух. Це ті критерії, використання яких в тих чи інших геостратегічних сценаріях дає змогу здійснювати вплив і контроль геополітичного простору інших держав.

X. Моргентау, визначаючи національну силу держави, виокремив дев'ять характеристик: географічне положення, природні ресурси, промислові можливості, військова підготовленість, чисельність населення, національний характер, національна мораль, якість дипломатії, якість уряду.

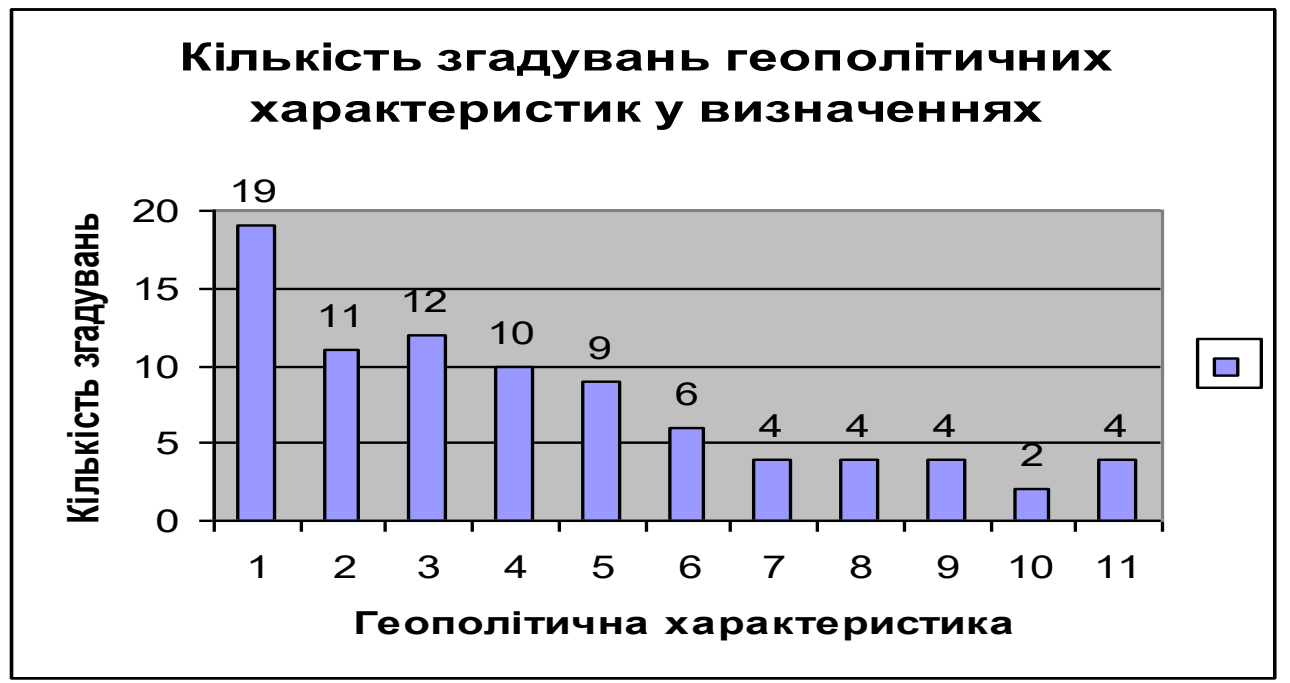

Рис. 1. Кількість згадувань геополітичних характеристик у визначеннях

1 - географічне положення, 2 - площа території, 3 - природні ресурси, 4 - чисельність населення,

5 - структура населення, 6 - клімат, 7 - топографія, 8 - релігійна складова, 9 - військова міць,

10 - екологія, 11 - економіка. За одним згадуванню - якість дипломатії, якість уряду, взаємовідносини між державами та регіонами, умови для сільськогосподарського виробництва, доступ до морів і океанів, національний дух, національний характер, національна мораль

Проведений аналіз дає змогу виділити основні характеристики (див. рис. 2), які можливо використовувати для опису, аналізу та реалізації геополітики (далі - геополітичні характеристики):

географічні (положення, вихід до моря, наближеність до транспортних маршрутів, комунікацій, шляхів транспортування);

демографічні (кількість, склад і якість народонаселення, показники фізичного здоров'я, вікова структура населення, міграція, від’ізд/приїзд висококваліфікованих фахівців, етнічний склад населення тощо);

економічні

(фінансовий

стан, схильність до кредитів, природні ресурси тощо);

кліматичні (широта, висота, рельєф, віддаленість від морів, океанів, наявність океанічних течій, розміщення на материку, характер підстилаючої поверхні тощо);

релігійні (склад i якість релігійних культур, характер взаємодії та взаємовпливу релігій, етнорелігійні групи, характер їх розселення);

історичні (використання історичних подій, фактів, документів; втручання у внутрішні справи інших держав; ставлення під сумнів легітимність підписаних документів в минулому; призупинення виконання історичних домовленостей в односторонньому порядку тощо);

політичні (“вага" політичної системи держави на світовій арені, дипломатія, підкуп еліти; підтримка сепаратистських рухів, тероризму; дроблення держав; державні перевороти тощо);

інформаційні (проведення психологічних операцій, інформаційна диверсія; активне розповсюдження відео- і аудіопродукції тощо); воєнні (воєнний потенціал, якість ЗС, постать керівника тощо);

етнічно-культурні

(наявність, стимулювання та підтримка народних меншин).

Тобто, геополітична характеристика це такий чинник, ознака, відносно якої можливо розглядати державу, як єдиний організм i, водничас, як політичний простір, відносно (навколо) якого відбуваються певні дії. Тобто, це ті чинники, які можливо використовувати для опису, аналізу та реалізації геополітики, ті ознаки, широкомасштабним та системним впливом на які можливо обумовлювати геополітику держав. 
3 викладеного можна дійти висновку, що такий чинник, як геополітична характеристика, вагомо впливає на загальну геополітику держави відносно інших суб'єктів геополітики. Саме такі країни, які мають в своїй характеристиці (щодо інших країн) кращі, більші і вигідніші географічне положення, площу своєї території, багаті природні ресурси, велику чисельність населення і відповідну структуру населення вони, як правило, і мають вагоміший вплив у світовій геополітиці (США, Китай, Росія, Німеччина тощо).

\section{ГЕОПОЛІТИКА}

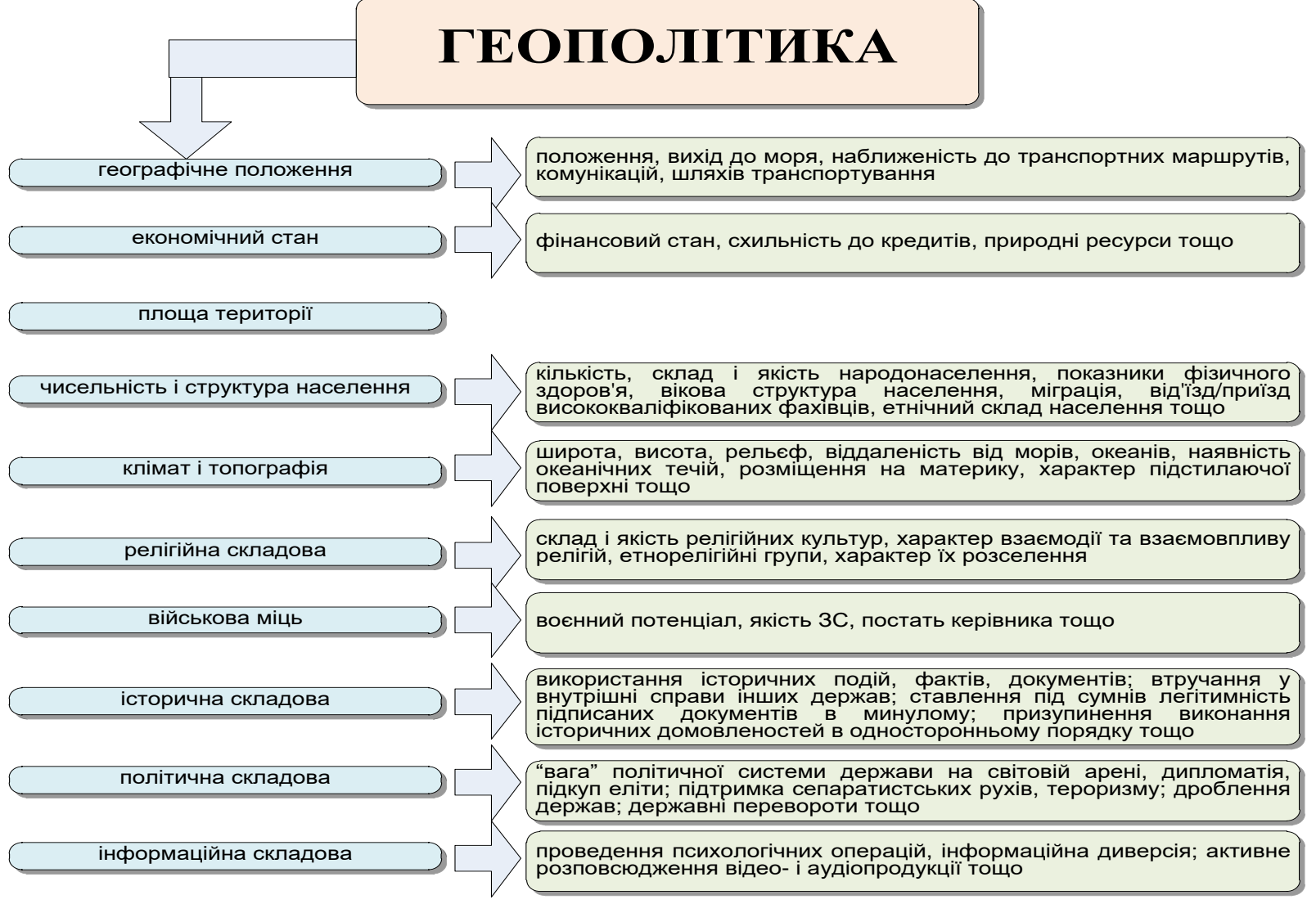

Рис. 2. Основні характеристики геополітики

У табл. 1 наведено форми реалізації геополітики державами (коаліціями).

\begin{tabular}{|c|c|}
\hline ФОРМИ & ХАРАКТЕРИСТИКА ФОРМИ \\
\hline Географічні & $\begin{array}{l}\text { Географічне положення, природні ресурси держави реалізуються у таких формах: } \\
\text { використання географічного розташування держави щодо належності до тих чи інших } \\
\text { регіонів, до комунікацій, шляхів транспортування (особливо енергоносіїв); використання } \\
\text { природних ресурсів як товарної експансії, шантаж сировиннозалежних держав тощо }\end{array}$ \\
\hline Історичні & $\begin{array}{l}\text { Багата історична спадщина реалізується у таких формах: використання історичних подій, } \\
\text { фактів, документів для обгрунтування сучасних експансіоністських намірів і втручання у } \\
\text { внутрішні справи інших держав; висвітлення суперечностей між історичними документами } \\
\text { та намагання перегляду їх положень через міжнародні судові органи; ставлення під сумнів } \\
\text { легітимність підписаних документів у минулому; призупинення виконання історичних } \\
\text { домовленостей в односторонньому порядку тощо }\end{array}$ \\
\hline Політичні & $\begin{array}{l}\text { Розвиток політичної системи держави та ії політична “вага" на світовій арені, дипломатія } \\
\text { використовуються у таких формах: проведення переговорів, візитів, спеціальних } \\
\text { конференцій і нарад для поширення впливу держави на простір інших акторів та } \\
\text { обмеження іх суверенітету за допомогою підписання договорів, хартій, залучення до } \\
\text { членства в союзах, міжнародних організаціях, блоках; політичний тиск (погрози введення } \\
\text { санкцій, ультиматуми та ін.); підкуп центральної еліти; підтримка сепаратистських рухів; } \\
\text { тероризм як крайній прояв політичної боротьби; дроблення держав, їх регіоналізація; } \\
\text { палацові та державні перевороти; спроби відкликати підписи своєї сторони під } \\
\text { міжнародними договорами, резолюціями тощо або затягування (відмова) їх ратифікації } \\
\text { парламентом держави і т. ін. }\end{array}$ \\
\hline Економічні & $\begin{array}{l}\text { Держава із розвинутою економікою використовує такі форми впливу й контролю } \\
\text { геополітичного простору: створення в інших країнах координаційних, моніторингових та } \\
\text { інших представництв, відкриття філій міжнародних економічних, фінансових організацій, } \\
\text { інформаційних аналітичних центрів, сумісних підприємств; будівництво на території інших } \\
\text { країн промислових об'єктів і об'єктів інфраструктури, постачання ї устаткування } \\
\text { (особливо важливо без надання можливості іх обслуговування самостійно, тобто без }\end{array}$ \\
\hline
\end{tabular}




\begin{tabular}{|c|c|}
\hline ФОРМИ & ХАРАКТЕРИСТИКА ФОРМИ \\
\hline & 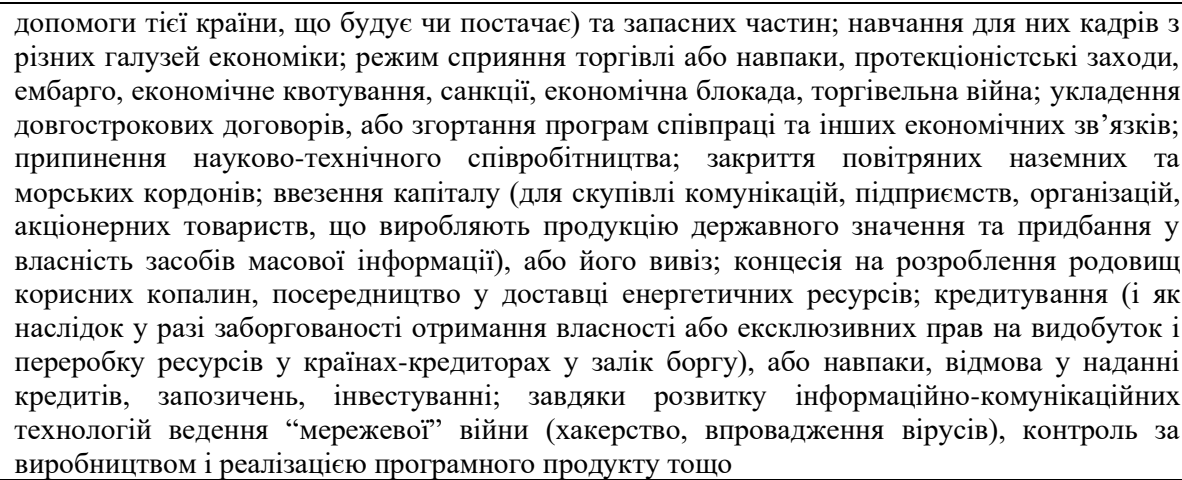 \\
\hline Воснні & $\begin{array}{l}\text { Воєнний потенціал держави використовується у таких формах: безпосереднє застосування } \\
\text { військової сили (війна, збройний конфлікт, блокада) або погроза ії застосувати; проведення } \\
\text { “планових" і надзвичайних військових навчань у безпосередній близькості від кордонів } \\
\text { геополітичного суперника або в спірному регіоні, маневри сухопутних військових } \\
\text { підрозділів, літальних апаратів, військових кораблів і підвідних човнів у стратегічно } \\
\text { важливих регіонах, випробування нових видів зброї, розміщення військових баз і засобів } \\
\text { електронної розвідки, активна діяльність спецслужб тощо }\end{array}$ \\
\hline Інформаційні & $\begin{array}{l}\text { Розвинуті інформаційні технології держав дають змогу здійснювати інформаційно- } \\
\text { психологічний вплив на геополітичного супротивника у таких формах: проведення } \\
\text { психологічних операцій спрямованих на розпалювання національної ворожнечі, } \\
\text { націоналістичних і інших дестабілізуючих настроїв, дискредитацію керівників держави та } \\
\text { підрив довіри до структур влади; створення і поширення міфів, як з позитивним, так і } \\
\text { негативним змістом; інформаційна диверсія; впровадження ментальних цінностей, зразків } \\
\text { культури, мистецтва держави-експансіоніста в масову свідомість держави-реципієнта, } \\
\text { активне розповсюдження відео- і аудіопродукції; намагання переорієнтувати освітні } \\
\text { системи і наукові напрями конкретної країни на цінності іншої тощо }\end{array}$ \\
\hline Демографічні & $\begin{array}{l}\text { Кількість і якість народонаселення (рівень освіти та виробничої кваліфікації, показники } \\
\text { фізичного здоров’я, вікова структура населення) може слугувати ментальним } \\
\text { обгрунтуванням геополітичного розширення й використовуватися у таких формах: міграції, } \\
\text { силового захоплення фізичного простору сусідніх держав вищим ступенем якого є } \\
\text { демографічна агресія (незаконне проникнення одного етносу на територію проживання } \\
\text { іншого, що здійснюєтья у формі економічного й адміністративного закріплення); } \\
\text { стимулювання “відпливу розумів", тобто від’їзд висококваліфікованих фахівців на } \\
\text { постійну роботу і проживання у інші країни тощо. До того ж мігранти нерідко стають } \\
\text { провідниками геополітичних ідей матричних держав або етносів і чим більший приплив } \\
\text { висококваліфікованих фахівців-мігрантів, тим потужніший геополітичний вплив країни- } \\
\text { донора у “тілі” країни реципієнта }\end{array}$ \\
\hline $\begin{array}{l}\text { Етнічно- } \\
\text { культурні }\end{array}$ & 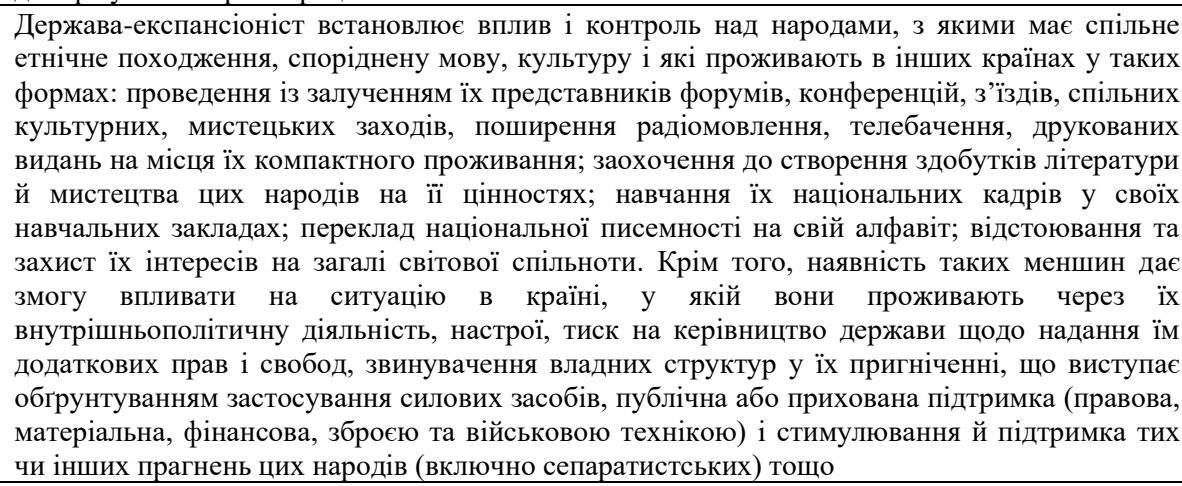 \\
\hline Релігійні & $\begin{array}{l}\text { Релігія використовується значною мірою в тих формах, що і етнічно-культурний засіб, } \\
\text { проте, можна додати такі способи: місіонерство, релігійні дії (хрестові походи, джихад), } \\
\text { навчання священнослужителів, будівництво храмів тощо. На сучасну георелігійну } \\
\text { ситуацію впливають як внутрішні, так і зовнішні чинники. До внутрішніх слід віднести } \\
\text { такі: логіка розвитку релігійного процесу; загальні тенденції розвитку релігійного життя за } \\
\text { кожної окремої релігії; характер взаємодії та взаємовпливу релігій; характер впливу } \\
\text { зовнішнього середовища, взаємодія з ним. Зовнішні чинники слід поділити на регіональні } \\
\text { та глобальні. До регіональних належать: природні особливості території; історія розвитку } \\
\text { та заселення території; демографічні характеристики населення та особливості розселення; } \\
\text { урбанізація та міграції; етнічний склад населення; етнорелігійні групи, характер їх } \\
\text { розселення; особливості природокористування; етногосподарські типи використання } \\
\text { території; рівень соціально-економічного розвитку території. Серед глобальних чинників } \\
\text { варто назвати: міжнародне становище; геополітичну ситуацію в регіоні; тенденції в } \\
\text { народонаселенні: демографічні, соціальні, етнічні, розселення, зайнятість і рівень життя; } \\
\text { глобальні та регіональні екологічні проблеми }\end{array}$ \\
\hline
\end{tabular}


Висновки та перспективи подальших досліджень. Проведений аналіз дає змогу дійти висновку, що через глибинніше вивчення геополітичних характеристик, можна найадекватніше здійснити прогноз воєннополітичної обстановки та надалі 3 більшою точністю дослідити агресивність держав. Тому подальші дослідження 3 проблем формування 1 розвитку геополітики держав стануть основою для розроблення геополітичної стратегії України з урахуванням глобальних загроз і викликів.

\section{СПИСОК ВИКОРИСТАНОЇ ЛІТЕРАТУРИ}

1. Бжезинский 3. Великая шахматная доска. Господство Америки и его геостратегические императивы [Текст] / 3. Бжезинский; пер. 3 англ. О. Ю. Уральской. - М. : Междунар. отношения, 1998. - 256 с.

2. Dalby S. Imperialism, domination, culture: The continued relevance of critical geopolitics S. Dalby // Geopolitics. 2008 - Vol. 13 (3). - P. 413-436.

3. Agnew J. Sovereignty Regimes: Territoriality and State Authority in Contemporary World Politics / J. Agnew // Annals of the Association of American Geographers. 2005. - 95 (2) - P. 437 - 461.

4. Mearsheimer J. Why the Ukraine Crisis Is the West's Fault. The Liberal Delusions That Provoked Putin [Electronic source] / J. Mearsheimer // Foreign Affairs. 2014. - Vol.93. - № 5 - Access mode: https://www.foreignaffairs.com/articles/russia-fsu/201408-18/why-ukraine-crisis-west-s-fault

5. Дорошко М. Вплив геополітичного середовища на зовнішню політикудержави (на прикладі країн пострадянського простору) /М. С. Дорошко // Географія і туризм - 2010. - Т.5. [Електронний ресурс]. - $\quad$ Режим доступу: http://www.geolgt.com.ua/images/stories/zbirnik/vipusk5/ v510.pdf

6. Перепелиця Г. Кремль реставрує російську імперію /Г.М. Перепелиця // Універсум. - 2011. - № 5/6. C. $15-29$.

Стаття поступила до редакційної колегії 11.07.2019
7. Чекаленко Л. Д. Засади взаємовідносин України і Росії: Крим /Л. Д. Чекаленко // Віче: громадсько-політичний $і$ теоретичний журнал. - 2014. - № 6. - С. 14-16.

8. Требін М. Армія наступного сторіччя: можлива модель для України // Людина і політика. - 2000. - № 2. - С. 3944.

9. Амирян В. Военно-политическая обстановка: методология и методика оценки: Автореф. дис. д-ра филос.наук:09.00.10/ГАВС. - М., 1992. - 44 с.

10. Амирян В. Методологические проблемы исследования военно-политической обстановки. - М.: ВПА, 1990. $166 \mathrm{c}$.

11. Данилов В., Молостов Б. Военно-политическая обстановка: проблемы анализа и оценки // Военная мысль. - 1989. - № 3. - С. 13-21.

12. Барынькин В. Планирование военного строительства: опыт и современность // Военная мысль. - 1995. - № 3. C. 12-20.

13. Киршин Ю. Оценка военно-политической обстановки: некоторые вопросы методологии и методики // Военная мысль - 1980. - № 2. - С. 14-22.

14. Барынькин B. Оценка военно-политической обстановки: методологический аспект // Военная мысль. - 1999. - № 5. - С. 23-30.

15. Смолянюк В. Воєнно-політична обстановка як ключова категорія воєнно-політичного аналізу та тенденції іï розвитку // Народна армія. -8 грудня, 1999. - C. 7.

16. Данилов В. Оценка военно-политической обстановки в структуре военной политологии // Военная мысль. 1991. - №4. - С. 34-36.

17. Плэтт В. Стратегическая разведка. Основные принципы. - М. : Издательский Дом «ФОРУМ», 1997. $376 \mathrm{c.}$

18. Никколо Макиавелли. О военном искусстве. - М.: Госе военное изд-во Наркомата обороны СССР, 1939. $222 \mathrm{c}$.

19. Хилсмэн Р. Стратегическая разведка и политические решения. - М.: Изд-во иностранной литературы, 1957. $190 \mathrm{c}$.

\section{Мазуренко И. Н.}

Центр военно-стратегических исследований Национального университета обороны Украины имени Ивана Черняховского, Киев

\section{Геополитические характеристики как форма реализации геополитики}

Резюме. В статье рассматривается содержание гипотезы, которая подтверждает необходимость исследования геополитических характеристик как важного показателя влияния на геополитику и агрессивность держав.

Ключевые слова: военно-политическая обстановка; геополитика; геополитическая характеристика; агрессия; агрессивность; прогноз военно-политической обстановки.

\section{Mazurenko}

Center for Military and Strategic Studies of the National Defense University of Ukraine named after Ivan Cherniakhovskyi, Kyiv

\section{Geopolitical characteristics as a form of geopolitical implementation}

Resume. The article discusses the content of the hypothesis, which confirms the need to study geopolitical characteristics as an important indicator of the impact on geopolitics and the aggressiveness of the countries.

Keywords: military-political situation; geopolitics, geopolitical characteristic; aggression; aggressiveness, military-political forecast. 